\title{
GABAA receptors in the nucleus raphe magnus modulate firing of neurons in the trigeminocervical complex
}

\author{
W Supronsinchai", RJ Storer, J Hoffmann, AP Andreou, S Akerman, PJ Goadsby \\ From The European Headache and Migraine Trust International Congress \\ London, UK. 20-23 September 2012
}

\section{Background}

Nociceptive transmission in the spinal cord is modulated by descending projections from the nucleus raphe magnus (NRM) receiving tonic inhibitory inputs from GABAergic neurons. The NRM modulates transmission of craniovascular nociception, which is related to head pain, in the trigeminocervical complex.

\section{Objective}

To determine whether descending modulation of transmission of craniovascular nociception in the trigeminocervical complex involves GABA receptors in the NRM. If so, to characterize those GABA-receptors.

\section{Methods}

We used a model of trigeminovascular nociception in Sprague Dawley rats that measures transmission of craniovascular nociception in the trigeminocervical complex (TCC) by the firing of TCC neurons evoked in response to electrical stimulation of afferents from the middle meningeal artery, its branches, and periarterial meninges (MMA). To determine whether GABA receptors in the NRM modulate this nociceptive transmission, and to characterize the modulation, we microinjected GABA, and GABAA- and GABAB-receptor agonists and antagonists into the NRM.

\section{Results}

Microinjection of GABA into the NRM increased firing of TCC neurons evoked by stimulation of MMA afferents ( $\mathrm{p}$ $<0.05$ ). Moreover, microinjection of the GABAA receptor agonist, muscimol, into the NRM also increased evoked firing of TCC neurons. Whereas the GABAA receptor antagonist, bicuculline, decreased evoked firing of TCC

Headache Group, Department of Neurology, USA neurons when microinjected into the NRM ( $\mathrm{p}<0.05)$. In contrast, microinjection of neither the GABAB receptor agonist, baclofen, or its antagonist, 2-hydroxysaclofen, into the NRM had no significant effect on the evoked firing of TCC neurons.

\section{Conclusion}

This study shows that inhibition of NRM neurons by GABAA-receptor activation facilitates transmission of craniovascular nociception in the trigeminocervical complex. Our results suggest that GABAA receptors in the NRM play a role in the pathophysiology of migraine and other primary headache disorders.

Published: 21 February 2013

doi:10.1186/1129-2377-14-S1-P67

Cite this article as: Supronsinchai et al:: GABAA receptors in the nucleus raphe magnus modulate firing of neurons in the trigeminocervical complex. The Journal of Headache and Pain 2013 14(Suppl 1):P67.

Submit your manuscript to a SpringerOpen ${ }^{\odot}$ journal and benefit from:

- Convenient online submission

- Rigorous peer review

- Immediate publication on acceptance

- Open access: articles freely available online

- High visibility within the field

- Retaining the copyright to your article

Submit your next manuscript at $>$ springeropen.com 